\title{
Some Provocations for a Future of Institutional Research: Evidence-Based Decision Making as Séance

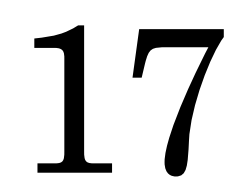

\section{Paul Prinsloo}

“... data are ... framed technically, economically, ethically, temporally, spatially and philosophically. Data do not exist independently of the ideas, instruments, practices, contexts and knowledges used to generate, process and analyse them."

(Kitchen 2014:2)

\section{Prologue}

The metaphors we use to describe and understand phenomena are not per se benign, but are consciously chosen to assist us in understanding a particular phenomenon. They also shape future understandings of the phenomenon to the exclusion of other understandings. As such, metaphors structure both thinking and action. Metaphors are "pattern-making devices that situate or locate patterns within their larger social contexts; they are [also] decentering devices" (Beddoes, Schimpf, \& Pawley 2014:3; emphasis added) that stimulate thinking and broaden/disrupt our epistemic boundaries. As such, a well-chosen metaphor can be a useful and important tool "to comprehend partially what cannot be comprehended totally" (Lakoff \& Johnson 1980:193). Using metaphor to describe phenomena also taps into a different vocabulary than definitions or terms of reference and allows us to access the phenomenon via a different access path, arriving at an enriched understanding of the phenomenon as experienced by the narrator (Shinebourne \& Smith 2010).

The metaphors we use to describe data, data collection and analysis offer an interesting view of the way in which we make sense of data, our assumptions and expectations. Data analysis is, for example, described as an 'art' (e.g. Ibrahim 2013), data as 'raw', 'cooked' 'corrupted' or 'cleaned' and its analytical processes described in terms of 'collected', 'entered', 'compiled', 'mined' and 'processed' (Gitelman \& Jackson 2013). (For an overview of the metaphors that are used to describe and engage with the phenomenon of (Big) Data, see Awati \& Buckingham Shum n.d.; Bell 2011; Mukunth 2015; as well as Puschmann \& Burgess 2014).

Birnbaum (2001) calls forth uncomfortable images when he compares predictive analytics with "the ancient practice of spilling the entrails of goats on the ground and reading messages from the patterns" (Trombley 1998 in Birnbaum 2001:199). Birnbaum (2001:199) furthermore states that "the reading of goat entrails was an ancient, messy, low-tech, and lost-cost precursor to environmental scanning" and that this practice was "tough on the goat, but in the hands of a skilled shaman probably no less accurate or useful than many current 
practices based on today's technologies." Reading goat entrails as a means of predicting the future or getting advice on how to make sense of current and future realities may seem out of place in the $21^{\text {st }}$ century, in the current need for information and strategic advice is compelling in several contemporary contexts.

At the outset, I would like to acknowledge the differences of opinion between a number of actors and stakeholders in the broad scope of institutional research actors (Kehm 2015; Teichler 2000). As Kehm (2015) indicates, there are different geographical models and (fragmented) understandings of institutional research. Teichler (2000:19) differentiates between the "discipline-based occasional higher education researcher", the "discipline-based continuous higher education researcher", the "theme-based academic higher education researcher", an "applied higher education researcher (e.g. institutional researcher", consultants and/ or evaluators and "reflective practitioners." In this chapter I broadly differentiate between researchers often scattered throughout the institution in disparate departments doing institutional research as one of their performance foci (whether occasionally, continuously or theme-based or as consultant or reflective practitioner), and institutional researchers located in (administrative or professional) dedicated units with the specific mandate and expertise to do (mostly) commissioned research to inform policy and institutional strategy (El-Khawas 2000; Kehm 2015; Teichler 2000). I therefore use the term 'institutional research' as an umbrella term referring to a variety of institutional research actors and practices (see Scott 2000). While I briefly explore the notion of 'third space professionals' as heralding the blurring of the strict boundaries and mandates of these researchers, I refer to Institutional Research or Institutional Researchers to acknowledge those in dedicated roles/departments where appropriate. No matter whether finding 'evidence' is a research interest or part of an individual's institutional mandate, this chapter explores the discourses underpinning and perpetuating evidence-based managed and its impacts.

I should advise the reader at this point that this chapter is critical and possibly irreverent about some of the assumptions informing present day analytical practices in higher education. In following Selwyn (2014a:10), I contest the "truthiness" and orthodoxies of optimism in the assumptions and claims surrounding evidence-based decision making in higher education. As such this chapter attempts "deliberately [to] slow down the pace of our discussions in the face of the fast-moving, rapidly changing and often ephemeral nature of the topic" (Selwyn 2014a:17) and contributes to the need for us to remain critical and restless, and possibly less certain about the claims we make. Allow me, therefore, to introduce the idea (metaphor) of séance at this point.

Firstly, and central to the practice of séance, is a critical and often urgent need for information that is not formally or naturally accessible. Most individuals who make use of séances to obtain information or to communicate with deceased loved ones have a critical need to do so, and would, in general, not consider this practice as 'normal' or part of their everyday lives. The critical need for information combined with the belief that there are sources of knowledge 'out there' is at the basis of the continued relevance of séances. Second, frustratingly for those in need of advice or information, these sources of information are coded and not accessible to those who 'cannot see' or who have not received the calling to act as interlocutors to translate the message. Those in need of information therefore 
turn to 'those in the know' who have the skills to decode the information and translate the information into advice. The last element within the context of the metaphor of the 'séance' is the impact (or lack of impact) of the reading or analysis on those who are looking for an answer.

\section{Introduction}

Since the 1960s, the issues surrounding the ability of research to improve teaching and learning (Brumbaugh 1960; Cross 1967) have increased in urgency and scope (see for example Boyer 1967; Clagett, Craig \& Robin 1993; Schwarz \& Teichler 2000; Teichler 2003; Terenzini 1993). The seemingly never-ending need for more data, analysis and prediction in higher education (Howard, McLaughlin, \& Knight 2012; Schildkamp, Lai \& Earl 2013) combined with the dominant narratives of a positivist, quantification fetish (Prinsloo 2014), the "neoliberal lexicon of numbers" (Cooper 2014: par. 5), the "tyranny of numbers" or "measurement mania" (Birnbaum 2001:197), should be understood against the backdrop of current uncertainties and flux in higher education.

Data, and specifically Big Data, "triggers both utopian and dystopian rhetoric" (Boyd \& Crawford 2012:663). It is not an overstatement (as many have claimed) that higher education has become "data-driven" (Selwyn 2014b:66), a notion which, alongside its corollary "evidence-based", can be understood amidst the "hum of corporate buzzwords" (Birnbaum 2001:3). These buzzwords or fads are "presented as universally applicable quickfix solutions - along with the obligatory and explicit caution that their recommendations are not quick fixes and will require substantial management understanding and commitment" (Birnbaum 2001:4). Management fads are also frequently presented as having magical properties - "The consultant or fad champion, like the tribal shaman, appears to be in touch with the gods" (Birnbaum 2001:8-9). Fads function as self-propagating memes which spread like a virus looking for hosts. Fads are also frequently political processes arising as a consequence of "the application of power by various interest groups at numerous levels" (Birnbaum 2001:11). As a kind of magical placebo, fads promise to cure an institutional illness... [See the last section of this chapter for an exploration of the different claims and uses of Institutional Research (IR)].

Picking up on this last metaphor, the magical placebo as cure for an illness, I would like now to explore evidence-based decision making as séance, with the illness, in this case, being the often alleged inefficiencies and ineffectiveness in higher education (Cross 2015; Ness \& Gándara 2014). In the context of current dominant paradigms of scientific management, Taylorism or managerialism in higher education (Birnbaum 2001; Enders 2015; Jarvis 2014), efficiency has become "the new watchword. It [is] scientific. It [is] progressive. It [is] the road to prosperity. And it require[s] a revolutionary new way of thinking on the part of both workers and managers" (Birnbaum 2001:15).

Exacerbating the 'illness' is the claim that the production of data "is increasingly becoming a deluge; a wide, deep torrent of timely, varied, resolute and relational data that are relatively low in cost and, outside of business, increasingly open and accessible" (Kitchen 2014: xv). It seems clear that we face intersecting phenomena that not only impact on, but also have the 
potential to alter dramatically, the way we teach and learn, and manage it. Yet, by accepting uncritically the current orthodoxies in evidence-based management, there is a real danger that higher education is swept along in "uncritically hyping the changes taking place, many of which raise numerous ethical, political, and legal concerns" (Kitchen 2014:xvi).

There is no doubt that evidence or data and the ethical harvesting and analysis of students' data can and should inform the management of teaching and learning, the development of curricula, and assessment and student support strategies and interventions (see e.g. Slade \& Prinsloo 2013; Schildkamp, Lai \& Earl 2013). There are, however, a number of authors who express concern regarding some of the basic assumptions, epistemologies and ontologies underlying the current hype in the discourses surrounding data-based decision making in education, especially with regard to teaching and learning (Biesta 2007 2010; Oliver \& Conole 2003; Pirrie 2001; Reeves 2011; and Swain 2013).

\section{Brief notes on my research approach}

A preliminary investigation into the discourses and practices surrounding evidencebased decision making in the context of Institutional Research revealed intersecting, and often overlapping fields of research such as, but not limited to, 'institutional research', 'data science', 'big data', 'evidence-based management', 'learning analytics' and 'policy development and implementation'. As such, it was impossible, within the limitations of this chapter, to engage thoroughly and comprehensively with all the literature and research findings covering these disparate fields. Following Fairclough (1992:3), who warns that "[d] iscourses do not just reflect or represent social entities and relations, they [also] construct or 'constitute' them", I was curious to engage with these disparate fields by attempting to make sense of texts and discursive practices that not only flow from existing power-relations and agencies pertaining to institutional research, but which are also constitutive of new relations and frameworks of meaning-making.

In looking for a methodology, there were a number of options such as (critical) discourse analysis (Fairclough 1992), a meta-analysis and synthesis of literature (Whittemore, Chao, Jang, Minges \& Park 2014), critical techno-cultural discourse analysis (CTDA) (Brock 2015; Dinerstein 2006; Hutchby 2001; Sweeney \& Brock 2014) and a scoping study (Arksey \& O'Malley 2005; Levac, Colquhoun \& O’Brien 2010; Colquhoun, Levac, O’Brien, Straus, Tricco, Perrier, Kasnter \& Moher 2014; Peters, Godfrey, Khalil, Mclnerney, Parker \& Soares 2015), to mention a few. Despite the potential of these approaches, I found it a serious challenge to choose one approach from the vast literature in a range of disciplinary contexts. Nevertheless, I elected to follow, in broad strokes, a Foucauldian approach to tentative scoping review and analysis by not focusing on linguistic analysis or equating discourse with language, but rather by focusing on discursive formations that not only flow from existing power-relations but which also perpetuate and sustain these relationships (Fairclough 1992). In this analysis I am particularly concerned with the ways in which data collection, analysis, interpretation and use are used to "extract and constitute knowledge" (Foucault 1979:185) and, in the process, to objectify, describe and analyse individuals as data objects and 'cases.' As such, in the gathering and analysing of data, the data analyst becomes the interlocutor 
and the "authority who requires the confession, prescribes and appreciates it, and intervenes in order to judge, forgive, console, and reconcile" (Foucault 1981:61).

Using the metaphor of 'séance' as my broad guiding framework and using the foci of the phenomenon of evidence-based management as fad, fashion or practice; the need for information and data; and the role of the data scientist as interlocutor while reflecting on the impact (or lack of impact) of Institutional Research on teaching and learning practices, I used the outlines of the scoping review as my basis. Scoping reviews are a relatively new methodology (Peters et al. 2015) and "are commonly used for 'reconnaissance' - to clarify working definitions and conceptual boundaries of a topic or field" (2015:141). Scoping reviews are a mapping exercise, "a process of summarizing a range of evidence in order to convey the breadth and depth of a field" (Levac et al. 2010:69). Arksey and O'Malley (2005:21) furthermore petition for the value of this approach in rapidly developing fields "where an area is complex or has not been reviewed comprehensively before." There are a number of limitations to scoping reviews such as the fact that the quality of the included studies is not assessed, making it almost impossible to interpret and finalise conclusions (Levac et al. 2010). In the light of the purpose of this chapter to open up and slow down the discourses surrounding the use of data in higher education, the conclusions in it provide merely a "crude map" (De Sousa Santos 2014:2) and resemble "border thinking ... [that] requires dwelling in the border" (Mignolo 2012,:xv).

The scoping review also allowed me to understand the impact of the surrounding culture and context in which the phenomenon occurs, as proposed by CTDA (Brock 2015; Dinerstein 2006; Hutchby 2001; Sweeney \& Brock 2014) where the phenomenon of evidence-based management is seen as mediated in a particular context, but also acting as mediator in that context. My use of a scoping review furthermore investigated the normative claims and assumptions about the technologies in question, as well as the associated beliefs and practices as a set of inter-related narratives including semiotic and material connections between form, function, beliefs, and practices. As such, my approach, in line with the purpose of CTDA, "point(s) to conceptual problematics that may be resolved through analysis, but not 'solved'" (Sweeney \& Brock 2014: par. 8).

Together with understanding evidence-based decision making as a mediated and mediating technology, we should see its claims, assumptions and disparate practices as entangled in/at the intersection of the impatience of policy makers to find quick answers/solutions (in line with their covert and overt political agendas) together with a variety of stakeholders and specialists who research the problem and serve as interlocutors or data shamans (see, for example, El-Khawas 2000).

In deciding on which texts and sources to use for the scoping review, I selected texts that inform and contest the implications and meanings of the metaphor of institutional research as séance. Using the metaphor as a guiding heuristic, I engaged with a range of resources and selected the main themes emerging from these resources. I acknowledge that the selection is subjective, but because this chapter avoids making normative claims and aims to open up the discussion, I judge the approach to be legitimate and functional. 
This chapter is structured as follows: I will firstly explore the broader context in/of higher education (in addition to the comments in the introduction) to understand the need for information, before mapping some of the beliefs about data and evidence as mediated and mediating technologies. I will then interrogate the data scientist as interlocutor, and, finally, explore some of the beliefs and impact on, or lack of impact on, institutional research. I will conclude with some cursory remarks on the future of institutional research.

\section{Scoping evidence-based decision making as fad, fashion and practice}

What are the origins of the need for evidence and data analysis and how does understanding this need for information and insight inform our expectations of data and analysis as technologies and unpack the role of the data scientist as interlocutor? In the context of the metaphor used in this chapter, we now turn to understanding the need for an interlocutor, or data shaman.

Considering the rationale for my collection of essays on evidence-based decision making in higher education for the purposes of this chapter, it is clear that evidence-based decision making or data-driven management is one of the meta-narratives in present-day higher education (Daniel 2015; Johnson, Becker, Estrada \& Freeman 2014; Mandinach \& Gummer 2015; Prinsloo et al. 2015; van Barneveld, Arnold, \& Campbell 2012). While managerialist discourses in higher education increasingly dictate a techno-rationalist (Selwyn 2014a) approach to education and data collection, many educational researchers and sociologists caution against the appropriateness of evidence-based practice (EBP) in education as an open, recursive and complex system (Biesta 2007, 2010; Clegg 2005; Davies 2003; Davies 1999; Elliot 2001; Oliver \& Conole 2003; Pirrie 2001; Simons 2003).

Looking at the higher education landscape, it is hard to ignore the claims and phrases currently dominating the literature (whether it is research or popular literature) such as "disruption" (e.g. Christenson \& Eyring 2011), "revolution" (Bulfin, Pangrazio, \& Selwyn 2014), and various claims of disruptive changes facing higher education (Charbonneau 2012; Fullick 2012; Pasquale 2015a). In the context of these claims of 'unprecedented' change, it is tempting to see (and present) these changes as recent phenomena while evidence suggests that claims regarding the 'end of the university' have been around since the early 1990s. The "McDonaldisation" of higher education, introduced by Hartley (1995:414), was characterised by the mantra of efficiency, quantification, calculability, predictability and control. Changes in funding regimes resulted in the directive that "funding ... follows performance rather than precedes it" (Hartley 1995: 418). According to LaCapra in 1998, "The university [was] in ruins." We could be forgiven feelings of déjà vu reading Eagleton's (2015) essay, "The slow death of the university", or Carey's (2015), "The end of college." Considering the claims since 1995 that higher education is nearing its end, it may not be so farfetched to suspect that higher education may have been caught up in an interregnum of constant crisis since the 1990s.

Altbach, Reisberg and Rumbley (2009) state that the trends characterising higher education present us with "an academic revolution" that includes the following shifts and trends: (1) the impact of globalisation; (2) the phenomenon of massification; (3) inequalities in access; 
(4) increasing student mobility; (5) changes in teaching, learning and curricula as well as (6) changes in quality assurance, accountability, and qualification frameworks; (7) the financing of higher education and (8) the public good - private good debate; (9) the immense growth in private higher education and (10) dramatic changes in the academic profession; (11) the research environment; and (12) the impact of advances in information and communications technology. Looking to the future, Altbach et al. (2009: xx) forecast that governments will continue to cut their funding support for higher education, higher education institutions will (need to) implement far-reaching cost-cutting measures resulting in the decline of quality, more part-time faculty are likely to be hired, class sizes will increase, the appointment of more staff will be placed on hold and will increasingly rely on information technology, which promises to make everything faster, more efficient and of course, cheaper (see Mahmud 2015). The latter resembles a certain 'techno-romanticism' (Selwyn 2014a) amidst claims that data, more data and analysis, will help higher education to become more efficient, effective and accountable. Evidence-based decision making may therefore be seen as "white magic", as a secular theology leading to pure knowledge of the unknowable, leading us to the new Jerusalem (Dinerstein 2006).

In the context of increased internationalisation and competition, higher education increasingly sells education as a privatised and mostly costly commodity, with an emphasis on a return on investments, just-in-time products delivered by just-in-time labour aiming to get the products (aka students) off the shelves in the shortest possible time. The efficiency of higher education is monitored and evaluated by auditing and control processes harvesting and analysing data and evidence as 'rituals of verification' (Power 1999 2004). Higher education increasingly resembles "Auditland" (Murphie 2014:10). These 'rituals of verification" and auditing processes beget more auditing processes in never-ending cycles that affect all learning and teaching (Murphie 2014). Auditing as mediated and mediating tool in service of evidence-based decision making creates technical systems that simultaneously serve as prosthetics and as parasites, supplementing and replacing authentic learning and frantically monitoring "little fragments of time and nervous energy" (Murphie 2014:19).

The reader may well wonder what the alternatives to evidence-based management practices are? A counter-argument would be to moot the possibility that in the light of the current dominant managerialist approaches and increasing funding constraints, the possibility of alternatives to evidence-based management practices being seriously considered is not likely. As Biesta $(2007,2010)$ indicates, the epistemological and ontological dimensions of evidence-based management require deep and critical reflection. To address the inherent knowledge, efficacy, and application deficits in evidence-based management and education, Biesta (2010:500) proposes, as an alternative, to move towards a "value-based education" as alternative. This proposal does not "suggest that evidence plays no role at all in value-based education, but is to highlight that its role is subordinate to the values that constitute practices as educational practices" (2010:493). Biesta (2010) raises a number of further issues, asking 'who's values', normativity and power are relevant. "The point again is that if we wish to use any knowledge about possible relationships between actions and consequences, there is still an important judgement to be made as to whether we wish to apply this knowledge and this, again, is a value judgement" (2010:500). So, while evidence 
may suggest that an intervention is effective, it does not, per se, provide any judgement whether the intervention was appropriate.

In the next section I turn to the description of data as "little fragments of time and nervous energy" as a heuristic lens on some of the normative beliefs and assumptions about data.

\section{Scoping the discourses pertaining to data}

Higher Education Institutions have continued access to ever increasing volumes, velocity and varieties of student digital data that allow us to expand not only on the traditional scope of institutional research with regard to student data, but also to infer relations unthinkable ten years ago. We may therefore be tempted to look for patterns without critically considering our own assumptions and epistemologies regarding data. Silver (2012:162) warns that in noisy systems with underdeveloped theory there is a real danger in mistaking noise for signals, not realising that noise pollutes our data with false alarms "setting back our ability to understand how the system really works." We generally accept data as "neutral, objective, and pre-analytic in nature, [while] data are in fact framed technically, economically, ethically, temporally, spatially and philosophically. Data do not exist independently of the ideas, instruments, practices, contexts and knowledges used to generate, process and analyse them" (Kitchen 2014:2).

Data are more often than not presented as facts and it is crucial that we understand that "facts are ontological, evidence is epistemological, [and] data is rhetorical... When a fact is proven false, it ceases to be a fact. False data is data nonetheless" (Rosenberg 2013:18; emphasis added. For an overview of the origin of the word and use of 'data' see Rosenberg, 2013). While in many current discourses we equate data with evidence, Rosenberg (2013) points out that the etymology of 'data' is contrasted with that of 'evidence': "Data has no truth. Even today, when we speak of data, we make no assumptions at all about veracity" (Rosenberg 2013:37). Kitchen (2014) however indicates that the relationships between data, information, knowledge and wisdom are much more contested (and complex) than is often presumed. (See Floridi 2012, for an exploration on the epistemological issues in "Big Data" and the 'black art" of analysis). Whatever one's take is on the different nuances and meanings of data and information, Floridi (2010, in Kitchen 2014:10) suggests that as information "adds meaning to data, its [data] gains currency as a commodity" and therefore increases its commercial and exchange value.

Selwyn (2014b:69) proposes that a specific sociological approach, when considering the role and purpose of data collection, analysis and use, "tends to start from the contention that data are political in nature - loaded with values, interests and assumptions that shape and limit what is done with it and by whom." Selwyn therefore warns that of specific concern is "how digital data are implicated in the reproduction of existing social inequalities as well as implicated potentially with the generation of new forms of inequality" (2014b:71). Data needs therefore to be considered and "problematised in terms of power, control, domination and inequality" (Selwyn 2014b:71). Having access to data sets informs particular notions of 'knowing more' and results in a "knowing capitalism" that supports and ensconces a "new form of knowing managerialism within educational settings" (Selwyn 2014b:72). Kitchen 
adds to this idea, noting that data are increasingly constituted as an economic resource: "Data can thus be understood as an agent of capital interests" (Kitchen 2014:16). (Also see Thrift 2005).

In sum, perhaps we need to take seriously Boyd and Crawford $(2012,2013)$ who recommend that we consider, trouble (as verb) and problematise data as a mediated and mediating phenomenon and discourse.

\section{Data changes the definition of knowledge}

Our engagement with data (whether big or small) essentially "reframes key questions about the constitution of knowledge, the processes of research, how we should engage with information, and the nature and the categorisation of reality" (boyd \& Crawford 2012:665). There are claims that "with enough data, the numbers speak for themselves" (MayerSchönberger \& Cukier 2013:14) and that it is no longer necessary to contemplate why people do things, but more important to track patterns in what they do. Not only does this result in an equation between data and knowledge, it also privileges trends as knowledge: "And herein lies the dilemma. Data cannot speak for itself" (Prinsloo et al. 2015:288). MayerSchönberger and Cukier (2014) also claim that $n=$ all and the fact that we have big data sets allows us to make generalisations and claims to 'Truth.' These assumptions result in claims to objectivity and accuracy that are not only misleading, but also dangerous, and reveal "an arrogant undercurrent in many Big Data debates" (boyd \& Crawford 2012:666). In contrast to the claims by Mayer-Schönberger and Cukier (2014), Kitchen states that data "are epistemological units, made to have a representational form that enables epistemological work, and data about the same phenomena can be measured and recorded in numerous ways, each providing a different set of data that can be analysed and interpreted through varying means" (2014:19).

There should always be doubts "about the veracity of data because they are inherently abstracted, generalised and approximated through their production" (Kitchen 2014:13). It is therefore crucial that we understand that the nature of our technical engagement shapes the extent to which data is an effective/holistic "surrogate for some aspect of a phenomenon" (Kitchen 2014:13). Data functions as a means by which ideologies and political agendas can be sanctioned, legitimated and conducted and have "greater rhetorical value than anecdote or sentiment" (Kitchen 2014:16). Gitelman and Jackson (2013:2) refer to Bowker who states that data are always "cooked" and never entirely "raw": "At first glance data are apparently before the fact: they are the starting point for what we know, who we are, and how we communicate. This shared sense of starting with data often leads to an unnoticed assumption that data are transparent, that information is self-evident, the fundamental stuff of truth itself". Data therefore "need to be understood as framed and framing" (Gitelman \& Jackson 2013:5; emphasis added). Kitchen (2014:9) points to the differences of opinion regarding the nature and dissimilarities between data, information, knowledge and wisdom, while the order or sequence of the concepts as processes of distillation "is generally uncontested." Not all forms of knowledge originate from data (e.g. opinions and/or beliefs), but there is general agreement that "access to high-quality and extensive data has a competitive advantage over those excluded from being able to generate understanding and wisdom (Kitchen 2014:12). 
For an overview of different authors' perspectives on data, information, knowledge and wisdom, see Floridi (2010), Kitchen (2014), and Zins (2007).

\section{Bigger data are not always better data}

We also assume that bigger or more data are necessarily better and that the combination of data from disparate data sources will result in a more holistic picture (Prinsloo et al. 2015). But, as boyd \& Crawford claim: "Big Data and whole data are not the same. Without taking into account the sample of a data set, the size of the data set is meaningless" (2013:669). Researchers have to account for "not only the limits of the data set, but also the limits of which questions they can ask of a data set and what interpretations are appropriate" (Boyd \& Crawford 2013:670). There seems to be a belief that the combination of different data sets increases the potential for understanding a phenomenon, often forgetting that the combination of different data sets also raises a number of unique challenges (Bollier 2010). "The sheer size of analysis does not eschew the limitations of subjectivity" resulting in the "unbearable lightness of information" (Papacharissi 2015:1097).

\section{Taken out of context, data loses its meaning}

"Not every connection is equivalent to every other connection, and neither does the frequency of contact indicate strength of relationship" (boyd \& Crawford 2013:671). Not only is "context... hard to interpret at scale", context becomes even more troublesome "when data are reduced to fit into a model" (boyd \& Crawford 2013:671). Nissenbaum (2015: par.7) points to the fact that the White House Consumer Privacy Bill of Rights and within it, the Principle of Respect for Context (PRFC), do provide for "'companies [to] collect, use, and disclose personal data in ways that are consistent with the context in which consumers provide the data" but she warns that "context is a mercilessly ambiguous term with potential to be all things to all people. Its meanings range from the colloquial and general to the theorised and specific, from the banal to the exotic, the abstract to the concrete, and shades in between." As such, 'context' has many possible meanings, such as the context of the technology platform or the context of the social domain or sector/industry; but we also need to consider privacy and the protection of privacy in the context of the relationship. (For a full discussion on these contexts, see Nissenbaum 2015). Nissenbaum (2015: par.7) proposes the notion of 'contextual integrity' to address the inappropriate flows of information between and out of contexts, thus providing "a more highly calibrated view of factors relevant to privacy than traditional dichotomies such as disclose/not disclose, private/public." Seaver (2015:1105) states that contexts are not stable collections of data points but "relational properties occasioned through activity."

\section{Just because it is accessible does not make it ethical}

There are increasing concerns that despite the anonymisation of data its corollary, the deanonymisation, seriously compromises research integrity and privacy (Rubinstein \& Hartzog 2015). What does informed consent look like when research participants do not know how their data will be combined in future downstream use with other data sets? What does accountability look like in the context of downstream de-anonimisation of data? What is the potential of harm when data sets are combined without due consideration of the 
original context of the research? (Barocas \& Nissenbaum 2014; Lagoze 2104; Narayanan \& Shmatikov 2010; Tene \& Polonetsky 2012).

\section{The increasing scope and role of algorithms}

In the bigger discourses on Artificial Intelligence and machine learning, there are also, amidst the hype, concerns about "algorithmic accountability", the lack of transparency, the "black box' of algorithmic decision making (see Diakopolous 2014; Henman 2004; Kitchen 2014; Pasquale 2015b; Tene \& Polonetsky 2013) and the fact that algorithms are but "ideology in executable form" (Nakaruma 2013: par.3). There is mention of "the algorithm as institution" and the "algorithmic turn", (Napoli 2013:1), "algorithmic regulation" (Morozov 2013: par.15) and the "threat of algocracy" (Danaher 2014). Algorithms as mediated and mediating technology are found at the regulative, normative, and cultural-cognitive dimensions in the intersection between algorithm and institution where code becomes law (Napoli 2013, referring to Lessig 2006). The dual role of algorithms as mediated and mediating technologies, possibly resemble a "gnoseological turning point" with the potential of reducing "ontological entities, individuals, to standardised ones through formal classification" into algorithms and calculable processes (Totaro \& Ninno 2014:29).

In the discourses, practices and concerns raised about the design, scope and role of algorithms, it is interesting to note the attribution of human characteristics and agency to algorithms as if algorithms have the current ability to act independently of their human designers. In this context it is important to recognise that "Algorithms do not have agency. People write algorithms" (Ellis, n.d.).

\section{The limitations of students' digital data}

Against the backdrop of claims that "student data is the new oil" (Watters 2013) that enables universities to be data-driven (Wishon \& Rome 2012), there are also concerns that learning analytics only value the measurable (Richardson 2012), and that the "technocratic predictive logic" (Henman 2004) inherent in the emphasis on students' digital data, ignores the fact that students' digital footprints do not represent a total picture (see also Mayer-Schönberger 2009). In education, as an open and recursive system, Biesta $(2007,2010)$ expresses the concern that evidence of "what works" does not necessarily "work." (See Biesta 2007 and 2010 for a critique on the appropriateness of evidence-based decision making in educational contexts). Measuring and reporting on the effectiveness of an intervention or strategy does not say anything about the appropriateness of the intervention in a particular context.

\section{Scoping the identity, skills and roles of the data scientist}

In this section I turn my attention specifically to those administrative or professional staff whose mandate qualifies them as Institutional Researcher and who are located in dedicated administrative or professional units for Institutional Research (see the distinction made in the Prologue). In the higher education context of the (often) unquestioned frantic and over-thetop need for more data and evidence, these individuals as data analysts resemble shamanic interlocutors, those who have access to codified knowledge and who have the skill-set to interpret the code and relay its hidden message to the audience. 
Amidst the different terms and titles such as data developers, data researchers, data creatives and data business persons, the notion of the "data scientist" is emerging as an all-encapsulating title and is claimed to be "hottest" (Chatfield, Shlemoon, Redublado, \& Rahman 2014:2) or "sexiest" (Davenport \& Patil 2012) job title of the $21^{\text {st }}$ century. Data scientists have therefore been called "gods" (Bloor 2012), "rock stars" (Sadkowsky 2014), "high priests" (Dwoskin 2014; Nielsen 2014); "unicorns" (Dwoskin 2014), "engineers of the future" (van der Aalst 2014) and "game changers" (Chatfield, Shlemoon, Redublado, \& Rahman 2014:2).

Chatfield et al. (2014:2) propose that with the growing need for evidence and analysis on the one hand, and the availability of disparate sources and expanding amounts of data on the other, the demand for "data scientists" has exponentially increased: "Despite the assertion that the job of a data scientist is 'the hottest job title', however, there is no rigorous definition of a data scientist in the literature." There is also no agreement on the exact scope of skills-sets or roles needed. Walker (2015:8) states: "The Data Science Association defines 'Data Science' as the scientific study of the creation, validation and transformation of data to create meaning, and the 'Data Scientist' as a professional who uses scientific methods to liberate and create meaning from raw data (sic)." Walker (2015:9) also states that "6\% of data science professionals have a Doctorate, $42 \%$ a Master's Degree, $11 \%$ a Bachelor's Degree and $1 \%$ no degree" and that there is market confusion about the definition of data science and the skills required of a data scientist" (Walker 2015:10).

Considering the huge expectations for Institutional Researchers to function also as data scientists, a number of authors map the skills and values needed by analysts in a range of contexts. Sanders (2003), for example, emphasises, inter alia, the following essential skills for a 'data scientist': an analytical skill-set, mathematics / statistics (including experimental design); domain knowledge (i.e. industry specific processes where analytics are applied); communication skills (story-telling); curiosity (willingness to challenge the status quo); collaboration and problem-solving skills (see also Chapters 4 and 5). In an interesting exploration, Harris, Murphy and Vaisman (2015) state that the notion of the 'data scientist' actually encompasses four historically distinct roles, if not professions, namely that of data developers (who are strong on machine learning, programming with overall good analytic acumen), data researchers (specialising in analysis and who are disproportionally strong in statistics), data creatives (who are all-rounders in statistics, machine learning and programming) and data business persons (who are disproportionately strong in business acumen, with a strong grounding in statistics). We also need to understand the search for consensus on the roles and definition of a 'data scientist' against the backdrop of the discourses on the professionalisation of data science (Walker 2015). The professionalisation of the 'data scientist' is furthermore complicated by the wide range of current expertise and practice. "The practice of law has about 24 different practice areas. The practice of medicine has approximately 17 specialties. Like law and medicine, data science is a vast and complicated field and much too big and complex for one person to master in one lifetime" (Walker 2015:11).

A further (possibly worrying) trend in the discourses surrounding the definition and scope of the roles of data scientists as distinct professionals is the dominance of a techno-romantic 
approach to data and analysis, and a lack of ample conceptual and critical engagement with data and analytical processes (Kitchen 2014). There are, however, glimpses of critical data studies as an emerging discourse and even as a discipline (boyd \& Crawford 2013; Dalton \& Thatcher n.d.; Kitchen 2014; Kitchin \& Lauriault 2014). Recently DJ Patil, the U.S. Chief Data Scientist, made it clear that "Every data scientist in this country must take a data ethics class. Just because we can, doesn't mean we should" (Shapiro 2015). (Also see Pryor \& Donnelly 2009).

Amidst the hype regarding what data can and cannot do, and the claims that pitch data scientists as gods, high priests of data or mediums, there is another view, for example, by Walker (2015), that despite claims to the contrary, data scientists are (unfortunately?) human after all. Walker (2015:11) states: "Humans... interpret meaning from data in different ways. Data scientists can be shown the same sets of data and reasonably come to different conclusions. Naked and hidden biases in selecting, collecting, structuring and analysing data present serious risks. How we decide to slice and dice data and what elements to emphasise or ignore influences the types and quality of measurements."

As a way forward, the potential in re-considering the role of the data scientist as 'third-space professional' (Childers 2014; Whitchurch 2013) in the context of higher education should be seriously considered. Whitchurch (2013:7) for example, suggests a reconsideration of professional roles in higher education according to four dispositions, namely, bounded professionals who "work within clear structural boundaries (e.g. function, job description)"; cross-boundary professionals referring to those individuals who "actively use boundaries for strategic advantage and institutional capacity building"; unbounded professionals who "disregard boundaries to focus on broadly-based projects and institutional development"; and blended professionals with "dedicated appointments spanning professional and academic domains".

These roles and identities not only relate to, but also determine, professional identity and agency within their respective departmental and institutional contexts and structures, relationships, knowledges and networks. Whitchurch (2013:8) points to an increasing blurring of the boundaries between strictly academic and professional roles creating a 'third space' where "individual positionings are not necessarily fixed or immutable, in that individuals may, for instance, occupy different forms of space at different stages of their career, or move between these according to circumstances." The notion of 'third-space professionals' poses a number of challenges to individuals and institutions such as accepting ambiguity and temporary arrangements, recruitment practices, and performance management. Anecdotal evidence suggests that while many institutions still see institutional researchers as 'bounded professionals', institutional researchers find themselves more and more alternating between cross-boundary, unbounded and blended positions in a 'third-space'.

\section{Scoping the role and impact of institutional research on teaching and learning}

"We didn't really get the information we needed when we wanted it, and it wasn't what we wanted when we got it" (Patton 2008:4) 
So far in this chapter I have attempted to (de)construct the need for data and evidence-based decision making in the current shifting sands of higher education. I have also dismantled some of our expectations and assumptions regarding data and data analysis as mediated and mediating tools, and I have dissected the role of the institutional data analyst as shaman or oracle.

Many institutional researchers (including all varieties) share the view that despite their best attempts to engage critically and ethically with requests for data and analysis, often at short notice, their analysis and recommendations are not taken seriously or possibly only read after the initial report-back meeting (see for example El-Khawas 2000; Kogan \& Henkel 2000). It falls outside the scope of this chapter to consider in detail the complexities and nuances of the (lack of) impact of institutional research. It may be sufficient to refer to El-Khawas (2000) who indicates that the impact (or lack of) is not necessarily owing to a lack of political will or ability, but should be understood against the backdrop of the need of managers and policy makers for practical, simple, and elegant solutions aligned to political and operational agendas and networks. Whether institutional research is called an "art" (Kogan \& Henkel 2000:25), "science" or "profession" (Neave 2000), there is some concern about the lack of take-up and "non-receptivity of policy-makers" (Kogan \& Henkel 2000:25). In the South African context, Fourie and Strydom (2000:183) state that "the influence of researchers in higher education research units has been minimal." Scott (2000:125) refers to "the present gulf" between higher education researchers and policy makers and practitioners and moots three main reasons for this state of affairs, namely (1) policy-makers and practitioners view much of the current research as irrelevant (whether because of themes/foci and/or the need for more customer-driven, shorter-term investigations); (2) the lack of academic quality; and (3) the perceived bias in higher education research.

Governments and management structures in higher education frequently face urgent problems where the stakes on personal or institutional reputation are very high. As such, these structures favour reductionist and positivist research modes rather than critical, interactive and qualitative modes. The original requests for data, analysis and evidence are phrased in terms that indicate a need to cut out complexity, turbulence and messiness with an emphasis on simple and uncomplicated findings and proposals that sponsors of the research can use and control (El-Khawas 2000). Kogan and Henkel (2000:32) refer to a government minister who stated "we don't need research to tell us what to do, we know that already." Governments and institutions of higher learning are furthermore not necessarily looking for the content, objectivity or the 'truth' of the research, but the Zeitgeist - "The 'successful' research well matches the intelligent wisdom of its time. If it is wisdom that accords with the views of those currently in power, then it will certainly be listened to" (Kogan \& Henkel 2000:34).

El-Khawas (2000) states that, in order for institutional or sponsored research to have any impact, three streams of stakeholders need to be involved, namely (1) the 'problem stream' - referring to individuals or stakeholders with information on the actual status and scope of the problem and a tacit understanding of what should be done; (2) the 'policy stream' - including advocates, researchers, and specialists who analyse problems and formulate alternatives and solutions; and (3) the 'political stream' including legislative and elected 
leaders with reputation, grand ideas and not much time to make a difference before they move on to their next position and/or project. If all three streams are not involved, then the likelihood of implementation or change becomes exponentially less (suggested by Kingdom, 1984, referred to in El-Khawas 2000). Implementation is effected when "a problem is recognised as serious and requiring a new solution; when the policy community develops a financially and technically workable solution; and when political leaders find it advantageous to approve it" (El-Khawas 2000:5; emphasis added).

El-Khawas (2000) therefore suggests that institutional researchers should contemplate the optimal use of opinion pieces, briefing documents and public forums specifically designed for researchers to speak to policy makers. It is also crucial that researchers, in their engagement with policy makers, listen and "recognise existing constraints; to observe the specific concerns of policy makers; and to listen for the gaps and opportunities for shaping new directions" (El-Khawas 2000:53). El-Khawas also suggests that researchers should understand the fluidity, if not fickleness, in the policy environment where policies are revised and reversed. So, even though the offered insights may not be valuable at a specific moment, it may well be that the same research findings may be listened to at a later stage: "... researchers may be better able to make a specific contribution to policy formulation when they offer their ideas as separable components, rather than as a single, multi-step plan or approach" (2000:54).

From the above it is an open question to what extent institutional research in all of its varieties and nuances impacts on teaching and learning. Considering the differences and varieties of contexts and actors, it would be arrogant to propose that institutional research does not, at all, impact on policy development in higher education. In the context of this chapter it is, however, clear that the future of institutional research in higher education will be shaped, inter alia, by how we respond to how we define 'evidence', how we select and analyse data and how we present our findings.

\section{(In)conclusions}

Though the need for data, analysis and sense-making in higher education has been an established feature of higher education since the 1960s, there is no doubt that the need for analysis and insight has never been greater. With higher education's increased access to student data, the proliferation of data sources, and increased technical sophistication to collect and analyse data, the managerial discourses around data and evidence have become a dominant meta-narrative in the current higher education landscape.

This scoping review allowed us to understand the different claims and functions of evidencebased practices as a mediated but also as a mediating phenomenon. In this chapter, I investigated a selection of core normative claims and associated beliefs and practices. The aim of this chapter was to "point to conceptual problematics that may be resolved through analysis, but not 'solved'" (Sweeney \& Brock 2014: par. 8). As such I situated institutional research and particularly evidence-based analysis as séance in the context where the rituals of measuring and verification act as prosthetics and as parasitic supplements, replacing 
authentic learning and frantically monitoring "little fragments of time and nervous energy" (Murphie 2014:19).

Silver (2012:11) reflects on the state of the art and science of prediction and warns that "our naïve trust in models, and our failure to realise how fragile they were to our choice of assumptions, yielded disastrous results." As we increasingly want to, and are compelled to, find patterns in (seemingly) random noise, and with "noise increasingly faster than the signal" (Silver 2012:13) there is an inherent danger that we are flying blind.

Amidst the noise and the frantic need to find a signal, we considered some of our assumptions about data, the role of the institutional researcher or data scientist as interlocutor, and the impact (or lack) of institutional research, necessarily, to increase student success and retention.

In closing I offer a number of pointers for a more nuanced and critical approach to collecting data for evidence, the analysis of the data, and the findings of data. Our beliefs and assumptions about data and our collection and analytics processes impact on the findings and on the lives of our students. As data scientists and analysts, we bear a responsibility. As we increasingly rely on the data we have and can collect, it is crucial that we remember that not only will our data frames be partial, but also that we cannot assume that $\mathrm{n}=$ all. To notice "what is happening" and to map patterns is the easy part. To explain 'why' this is happening is a different ball game and even more important. And yes, we need to stay critical, transparent, accountable and ethical.

\section{Epilogue}

In the "Prologue" to this chapter, I stated that the metaphors we use to describe and understand phenomena are not benign or neutral, but are consciously chosen to assist us in understanding a particular phenomenon. In writing this chapter, I found the use of the 'séance' as metaphor rewarding as it provided me with a "pattern-making device" (Beddoes, et al. 2014:3) within the broader context of the claims and counterclaims regarding data and evidence in higher education. I am very aware that, as such, the use of the 'séance' as metaphor excluded other possible interpretations. In purposefully choosing 'séance' as my interpretive lens I hoped to decentre or at the very least, dislodge some of the generally accepted assumptions and practices regarding institutional research in general, and evidence-based decision making in particular.

You, the reader of this essay, will judge the success of, and the extent to which, the metaphor of the 'séance' opened up new avenues for exploring the potential and limitations of data, analysis and the role of the institutional researcher as interlocutor in increasing the effectiveness of teaching and learning. 


\section{References}

Altbach, PG., Reisberg, L., \& Rumbley, LE. 2009. Trends in global higher education: Tracking an academic revolution. Retrieved from http:// www.researchgate.net/profile/ Philip_Altbach/publication/225084084 Trends_in_Global_Higher_Education_ Tracking_an_Academic_Revolution/ links/551ac4020cf251c35b4f5d0d.pdf

Arksey, H., \& O’Malley, L. 2005. Scoping studies: towards a methodological framework. International journal of social research methodology, 8(1), 19-32. http://dx.doi. org/10.1080/1364557032000119616

Awati, K., \& Buckingham Shum, S. n.d. Big Data metaphors we live by. [Web log post]. Retrieved from https://medium. com/@kailashawati/big-data-metaphorswe-live-by-98d3fa44ebf8

Barocas, S., \& Nissenbaum, H. 2014. Big data's end run around procedural privacy protections. Communications of the ACM, 57(11), 31-33. http://dx.doi. org/10.1145/2668897

Beddoes, K., Schimpf, CM. Pawley, AL. 2014. New metaphors for new understandings: ontological questions about developing grounded theories in engineering education. Paper presented at the 121st ASEE Annual Conference \& Exposition, Indianapolis, Indiana, June 15-18. Retrieved from http://www.asee.org/ public/conferences/32/papers/9010/ download

Bell, T. 2011, February 10. Big data: An opportunity in search of a metaphor. [Web log post]. Retrieved from radar. oreilly.com/2011/02/big-data-metaphor. $\mathrm{html}$

Biesta, G. 2007. Why "what works" won't work: evidence-based practice and the democratic deficit in educational research, Educational Theory, 57(1), 1-22. http://dx.doi.org/10.1111/j.17415446.2006.00241.x

Biesta, G. 2010. Why 'what works' still won't work: from evidence-based education to value-based education, Studies in Philosophy of Education, 29, 491-503. http://dx.doi.org/10.1007/s11217-0109191-x
Birnbaum, R. 2001. Management fads in higher education. Where they come from, what they do, why they fail. San Francisco, CA: Jossey-Bass.

Bloor, R. 2012, December 12. Are the data scientists future CEOs? [Web log post]. Retrieved from http://insideanalysis. com/2012/12/are-the-data-scientistsfuture-ceos/

Bollier, D. 2010. The promise and peril of Big Data. Eighteenth Annual Aspen Institute Roundtable on Information Technology. Retrieved from http://www. aspeninstitute.org/sites/default/files/ content/docs/pubs/The_Promise_and_ Peril_of_Big_Data.pdf

boyd, D., \& Crawford, K. 2012. Critical questions for big data. Information, Communication \& Society, 15(5), 662679. http://dx.doi.org/10.1080/136911 8X.2012.678878

boyd, D., \& Crawford, K. 2013. Six provocations for big data. Retrieved from http://papers.ssrn.com/sol3/papers. cfm?abstract_id=1926431

Boyer, EL. 1967. Institutional research and the academic program. New Dimensions in Higher Education, 20. Retrieved from http://eric.ed.gov/?id=ED013381

Brock, A. 2015. Deeper data: a response to boyd and Crawford. Media, Culture \& Society, 37(7), 1084-1088. http://dx.doi. org/10.1177/0163443715594105

Brumbaugh, AJ. 1960. Research designed to improve institutions of higher learning. Retrieved from http://eric. ed.gov/?id $=$ ED017141

Bulfin, S., Pangrazio, L., \& Selwyn, N. 2014. Making 'MOOCs': The construction of a new digital higher education within news media discourse. The International Review of Research in Open and Distributed Learning, 15(5), 290-305. http://dx.doi.org/10.19173/irrodl. v15i5.1856

Carey, K. 2015. The end of college. New York, NY: Riverhead Books.

Charbonneau L. 2012, June 5. The top three hoary metaphors of the higher-ed apocalypse. [Web log post]. Retrieved from http://www.universityaffairs.ca/ opinion/margin-notes/the-top-three- 
hoary-metaphors-of-the-higher-edapocalypse/

Chatfield, AT., Shlemoon, VN., Redublado, W., \& Rahman, F. 2014. Data scientists as game changers in big data environments. ACIS. Retrieved from http://www.researchgate.net/ publication/268078811_Data_Scientists as_Game_Changers_in_Big_Data_ Environments

Childers, JL. 2014. Reconstructing identities in higher education: The rise of third space professionals. Journal of Higher Education Outreach and Engagement, 18(3), 141-146.

Christensen, CM., \& Eyring, HJ. 2011. The innovative university: Changing the DNA of higher education from the inside out. New York, NY: John Wiley \& Sons.

Clagett, CA., \& Huntington, RB. 1993. Making a significant difference with institutional research. Retrieved from http://eric.ed.gov/?id=ED362239

Colquhoun, HL., Levac, D., O’Brien, KK., Straus, S., Tricco, AC., Perrier, L. Kastner, M., \& Moher, D. 2014. Scoping reviews: time for clarity in definition, methods, and reporting. Journal of clinical epidemiology, 67(12), 12911294. http://dx.doi.org/10.1016/j. jclinepi.2014.03.013

Cooper, D. 2014, December 5. Taking pleasure in small numbers: How intimately are social media stats governing us? [Web log post]. Retrieved from http://blogs.Ise.ac.uk/ impactofsocialsciences/2014/12/05/ taking-pleasure-in-small-numbers/

Cross, KP. 1967. When will research improve education? Retrieved from http://eric. ed.gov/?id=ED025206

Cross, M. 2015. State power, transition and new modes of coordination in higher education in South Africa. In Higher Education in the BRICS Countries (pp. 353-376). Springer Netherlands. http:// dx.doi.org/10.1007/978-94-017-9570$8 \_18$

Dalton, C., \& Thatcher, J. n.d. What does a critical data studies look like, and why do we care? Seven points for a critical approach to 'big data.' [Web log post]. Retrieved from http://societyandspace. $\mathrm{com} /$ material/commentaries/craig- dalton-and-jim-thatcher-what-does-acritical-data-studies-look-like-and-whydo-we-care-seven-points-for-a-criticalapproach-to-big-data/

Danaher, J. 2014. Rule by algorithm? Big data and the threat of algocracy. Institute for Ethics and Emerging Technologies. [Web log post]. Retrieved from http:// philosophicaldisquisitions.blogspot. com/2014/01/rule-by-algorithm-big-dataand-threat.html

Daniel, B. 2015. Big data and analytics in higher education: Opportunities and challenges. British Journal of Educational Technology, 46(5), 904-920. http:// dx.doi.org/10.1111/bjet.12230

Davenport, TH., \& Patil, DJ. 2012. Data scientist: The sexiest job of the 21st century - A new breed of professional holds the key to capitalizing on big data opportunities. But these specialists aren't easy to find - And the competition for them is fierce. Harvard Business Review, 70. Retrieved from https://hbr. org/2012/10/data-scientist-the-sexiestjob-of-the-21st-century/

De Sousa Santos, B. 2014. Epistemologies of the South. Justice against epistemicide. New York, NY: Routledge.

Diakopoulos, N. 2015. Algorithmic accountability: Journalistic investigation of computational power structures. Digital Journalism, 3(3), 398-415. http:// dx.doi.org/10.1080/21670811.2014.97 6411

Dinerstein, J. 2006. Technology and its discontents: On the verge of the posthuman. American Quarterly, 58(3), 569-595. http://dx.doi.org/10.1353/ aq. 2006.0056

Dwoskin, E. 2014. Big data's high-priests of algorithms. The Wall Street Journal, Aug, 8. Retrieved from http://tippie.uiowa. edu/management-sciences/wsj2014.pdf

Eagleton, T. 2015. The slow death of the university. The Chronicle of Higher Education, 6.

El-Khawas, E. 2000. Patterns of communication and miscommunication between research and policy. In S. Schwarz \& U. Teichler (Eds.), The institutional basis of higher education research. Experiences and perspectives 
(pp. 45-55). London, UK: Kluwer Academic Publishers.

Elliot, J. 2001. Making evidencebased practice educational. British Educational Research Journal, 27(5), 555-574. http://dx.doi. org/10.1080/01411920120095735

Ellis, W. n.d. Algorithms... Retrieved from http:/juhavantzelfde.tumblr.com/ post/117504109386/algorithms-do-nothave-agency-people-write

Enders, J. 2015. The winds of change and academic staff in Europe. International Higher Education, (21), 6-7.

Fairclough, N. 1992. Discourse and social change. Cambridge, UK: Polity Press.

Floridi, L. 2010. Information: a very short guide. Oxford, UK: Oxford University Press. http://dx.doi.org/10.1093/ actrade/9780199551378.001.0001

Floridi, L. 2012. Big data and their epistemological challenge. Philosophy \& Technology, 25(4), 435-437. http:// dx.doi.org/10.1007/s13347-012-0093-4

Foucault, M. 1979. Discipline and punish: The birth of the prison. Harmondsworth, UK: Penguin Books.

Foucault, M. 1981. History of sexuality, vol. 1. Harmondsworth, UK: Penguin Books.

Fourie, M., \& Strydom, K. 2000.

Relationships among higher education research, policy and practice in South Africa. In S. Schwarz \& U. Teichler (Eds.), The institutional basis of higher education research. Experiences and perspectives (pp. 181-192). London, UK: Kluwer Academic Publishers.

Fullick C. 2012. Failure, crisis, disruption: The (perpetual) end of higher ed. Retrieved from http://www.universityaffairs.ca/ opinion/speculative-diction/failure-crisisdisruption-the-perpetual-end-of-highered/

Gitelman, L., \& Jackson, V. 2013. Introduction, in Lisa Gitelman (ed.), "Raw data" is an oxymoron (pp1-14). London, UK: The MIT Press.

Harris, H., Murphy, S., \& Vaisman, M. 2013. Analysing the analysers: An introspective survey of data scientists and their work. O'Reilly Media, Inc. Retrieved from http://cdn.oreillystatic.com/oreilly/
radarreport/0636920029014/Analyzing the Analyzers.pdf

Hartley, D. 1995. The 'McDonaldisation' of higher education: food for thought? Oxford Review of Education, 21(4), 409-423. http://dx.doi. org/10.1080/0305498950210403

Henman, P. 2004. Targeted!: Population segmentation, electronic surveillance and governing the unemployed in Australia. International Sociology, 19, 173-191. http://dx.doi. org/10.1177/0268580904042899

Howard, RD., McLaughlin, GW., \& Knight, WE. (Eds.). 2012. The handbook of institutional research. San Francisco, CA: John Wiley \& Sons.

Hutchby, I. 2001. Technologies, texts and affordances. Sociology, 35(2), 441-456. http://dx.doi.org/10.1177/ S0038038501000219

Ibrahim, M. 2013. The art of data analysis. Retrieved from http://www. researchgate.net/profile/Muhammad Ibrahim7/publication/258415161 art of data analysis/ links $/$ 02e7e $\overline{5} 2827625779$ c3000000.pdf

Jarvis, DS. 2014) Regulating higher education: Quality assurance and neoliberal managerialism in higher education - A critical introduction. Policy and Society, 33(3), 155-166. http://dx.doi. org/10.1016/j.polsoc.2014.09.005

Johnson, L., Becker, S., Estrada, V., \& Freeman, A. 2014. Horizon Report: 2014 Higher Education. Retrieved from http://www.editlib.org/p/130341/

Jørgensen, M. \& Phillips, L. 2002. Discourse analysis as theory and method. London, UK: Sage Publications. http://dx.doi. org/10.4135/9781849208871

Kehm, BM. 2015. Higher education as a field of study and research in Europe. European Journal of Education, 50(1), 60-74. http://dx.doi.org/10.1111/ ejed. 12100

Kitchen, R. 2014. The data revolution. Big data, open data, data infrastructures and their consequences. London, UK: SAGE. http://dx.doi. org/10.4135/9781473909472

Kitchin, R., \& Lauriault, TP. 2014. Towards critical data studies: Charting and unpacking data assemblages and their 
work. The Programmable City Working Paper 2; pre-print version of chapter to be published in Eckert, J., Shears, A. and Thatcher, J. (eds) Geoweb and big data. University of Nebraska Press. Forthcoming. Available at SSRN: http:// ssrn.com/abstract $=2474112$

Kogan, M., \& Henkel, M. 2000. Future directions for higher education policy research. In S. Schwarz \& U. Teichler (Eds.), The institutional basis of higher education research. Experiences and perspectives (pp. 25-43). London, UK: Kluwer Academic Publishers.

LaCapra D. 1998. The university in ruins? Critical Inquiry, 32-55. http://dx.doi. org/10.1086/448907

Lagoze, C. 2014. Big data, data integrity, and the fracturing of the control zone. Big Data \& Society (July-December), 1-11. DOI: $10.1177 / 205395174558281$

Lakoff, G. \& Johnson, M. 1980. Metaphors we live by. Chicago: University of Chicago Press.

Levac, D., Colquhoun, H., \& O'Brien, KK. 2010. Scoping studies: advancing the methodology. Implement Science, 5(1), 1-9. http://dx.doi.org/10.1186/17485908-5-69

Mahmud, T. 2015. Precarious existence and capitalism: A permanent state of exception. Southwestern University Law Review, 15-12. Forthcoming; Seattle University School of Law Research Paper No. 15-12. Available at SSRN: http:// ssrn.com/abstract $=2597257$

Mandinach, E., \& Gummer, E. 2015. Datadriven decision making: Components of the enculturation of data use in education. Teachers College Record, 117(4), 1-12.

Mayer-Schönberger, V. 2009. Delete. The virtue of forgetting in the digital age. Princeton, NJ: Princeton University Press.

Mayer-Schönberger, V., \& Cukier, K. 2013. Big data. A revolution that will transform how we live, work, and think. New York, N.Y.: Houghton Miffling Harcourt Publishing Company

Mignolo, WD. 2012. Local histories/ global designs. Coloniality, subaltern knowledges, and border thinking. Princeton, NJ: Princeton
University Press. http://dx.doi. org/10.1515/9781400845064

Morozov, E. 2013, October 23. The real privacy problem. MIT Technology Review. Retrieved from http:// www.technologyreview.com/ featuredstory/520426/the-real-privacyproblem/

Mukunth, V. 2015, March 28. From Orwell to Kafka, Markov to Doctorow: Understanding big data through metaphors. [Web log post]. Retrieved from http://isnerd.co/2015/03/28/fromorwell-to-kafka-markov-to-doctorowunderstanding-big-data-throughmetaphors/

Murphie, A. 2014. Auditland. PORTAL Journal of Multidisciplinary International Studies, 11(2). Retrieved from https:// epress.lib.uts.edu.au/journals/index.php/ portal/article/view/3407/4525

Nakamura, L. 2013. Glitch racism: Networks as actors within vernacular Internet theory. Culture Digitally. Retrieved from http://culturedigitally.org/2013/12/ glitch-racism-networks-as-actors-withinvernacular-internet-theory/

Napoli, P. 2013. The algorithm as institution: Toward a theoretical framework for automated media production and consumption. In Media in Transition Conference (pp. 1-36). http://dx.doi. org/10.2139/ssrn.2260923

Narayanan, A., \& Shmatikov, V. 2010. Myths and fallacies of personally identifiable information. Communications of the ACM , 53(6), 24-26. http://dx.doi. org/10.1145/1743546.1743558

Neave, G. 2000. On fate and intelligence: The institutional base of higher education research. In S. Schwarz \& U. Teichler (Eds.), The institutional basis of higher education research. Experiences and perspectives (pp. 57-74). London, UK: Kluwer Academic Publishers.

Ness, EC., \& Gándara, D. 2014. Ideological think tanks in the states an inventory of their prevalence, networks, and higher education policy activity. Educational Policy, 28(2), 258-280. http://dx.doi. org/10.1177/0895904813515328

Nielsen, L. 2014. Unicorns among us: understanding the high priests of data 
science. Wickford, Rhode Island: New Street Communications.

Nissenbaum, H. 2015. Respecting context to protect privacy: Why meaning matters. Science and engineering ethics. Retrieved from http://link.springer.com/ article/10.1007/s11948-015-9674-9

Oliver, M., \& Conole, G. 2003. Evidencebased practice and e-learning in higher education: can we and should we? Research Papers in Education, 18(4), 385-397. http://dx.doi. org/10.1080/0267152032000176873

Papacharissi, Z. 2015. The unbearable lightness of information and the impossible gravitas of knowledge: Big Data and the makings of a digital orality. Media, Culture \& Society, 1-6. http:// dx.doi.org/10.1177/0163443715594103

Pasquale, F. 2015a. The university of nowhere: The false promise of "disruption." Los Angeles Review of Books [online]. Retrieved from https:// lareviewofbooks.org/review/theuniversity-of-nowhere-the-false-promiseof-disruption

Pasquale, F. 2015b. The black box society: The secret algorithms that control money and information. Cambridge: Harvard University Press. http://dx.doi. org/10.4159/harvard.9780674736061

Patton, MC. 2008. Utilisation-focused evaluation. [4th edition]. London, UK: Sage.

Peters, MD., Godfrey, CM., Khalil, H., Mclnerney, P., Parker, D., \& Soares, CB. 2015. Guidance for conducting systematic scoping reviews. International journal of evidence-based healthcare, 13(3), 141-146. http://dx.doi. org/10.1097/XEB.0000000000000050

Pirrie, A. 2001. Evidence-based practice in education: The best medicine? British Journal of Educational Studies, 49(2), 124-136. DOI: 10.1111/14678527.t01-1-00167. http://dx.doi. org/10.1111/1467-8527.t01-1-00167

Power, M. 1999.The audit society: Rituals of verification. 2nd edition. London, UK: Oxford University Press. http://dx.doi.org/10.1093/ acprof:oso/9780198296034.001.0001

Power, M. 2004. Counting, control and calculation: Reflections on measuring and management. Human Relations, 57(6), 765-783. http://dx.doi. org/10.1177/0018726704044955

Prinsloo, P. 2014, October 22. Mene, mene, tekel, upharsin: researcher identity and performance. Inaugural lecture at the University of South Africa. Retrieved from http://www.researchgate.net/profile/ Paul_Prinsloo/publication/267395307_ Mene_mene_tekel_upharsin researcher identity and performance/ links/544f2f200cf29473161bf642.pdf

Prinsloo, P., Archer, E., Barnes, G., Chetty, Y., \& Van Zyl, D. 2015. Big (ger) data as better data in open distance learning. The International Review of Research in Open and Distributed Learning, 16(1). http://dx.doi.org/10.19173/irrodl. v16i1.1948

Pryor, G., \& Donnelly, M. 2009. Skilling up to do data: whose role, whose responsibility, whose career? International Journal of Digital Curation, 4(2), 158-170. http://dx.doi.org/10.2218/ ijdc.v4i2.105

Puschmann, C., \& Burgess, J. 2014. Big data, big questions. Metaphors of big data. International Journal of Communication, 8, 1690-1709.

Reeves, T. 2011. Can educational research be both rigorous and relevant? Educational Designer. Journal of the International Society for Design and Development in Education. Retrieved from http://www. educationaldesigner.org/ed/volume1/ issue 4/article13/index.htm

Richardson, W. 2012, July 14 . Valuing the immeasurable. [Web log post]. Retrieved from http://willrichardson. com/post/27223512371/valuing-theimmeasurable

Rosenberg, D. 2013. Data before fact. In Lisa Gitelman (ed), "Raw data" is an oxymoron. London, UK: The MIT Press.

Rubinstein, I.S., \& Hartzog, W. 2015. Anonymization and risk. New York University Public Law and Legal Theory Working Papers. Retrieved from http://lsr. nellco.org/nyu_plltwp/530/

Sadkowsky, T. 2014, July 2. Data scientists: The new rock stars of the tech world. [Web log post]. Retrieved from https:// www.techopedia.com/2/28526/it- 
business/it-careers/data-scientists-thenew-rock-stars-of-the-tech-world

Sanders, MA. 2013, August 27. Data scientist core skills. [Web log post]. Retrieved from http://www.datasciencecentral.com/ profiles/blogs/data-scientist-core-skills

Schildkamp, K., Lay, MK, \& Earl, L. (eds). 2013. Data-based decision making in education. Challenges and opportunities. London, UK: Springer.

Schwarz, S., \& Teichler, U. (Eds.). 2000. The institutional basis of higher education research. Experiences and perspectives. London, UK: Kluwer Academic Publishers.

Scott, P. 2000. Higher education research in the light of the dialogue between policymakers and practitioners. In U. Teichler and J. Sadlak, (Eds.), Higher education research. Its relationship to policy and practice (pp. 123-150). Bingley, UK: Emerald Group Publishing Limited.

Seaver, N. 2015. The nice thing about context is that everyone has it. Media, Culture \& Society, 37(7), 1101-1109. http://dx.doi. org/10.1177/0163443715594102

Selwyn, N. 2014a. Distrusting educational technology. Critical questions for changing times. New York, NY: Routledge.

Selwyn, N. 2014b. Data entry: towards the critical study of digital data and education. Learning, Media and Technology, 40(1), 64-82, http://dx.doi. org/10.1080/17439884.2014.921628

Shapiro, B. [@Bill_Shapiro].2015, November 10. "“Every data scientist in this country must take a data ethics class. Just because we can, doesn't mean we should." Retrieved from https://twitter.com/Bill_Shapiro/ status/6640959581170̄64704

Shinebourne, P., \& Smith, JA. 2010. The communicative power of metaphors: An analysis and interpretation of metaphors in accounts of the experience of addiction. Psychology and Psychotherapy: Theory, Research and Practice, 83, 59-73. http://dx.doi. org/10.1348/147608309X468077

Silver, N. 2012. The signal and the noise: Why most predictions fail - but some don't. New York, NY: Routledge.
Simons, H. 2003. Evidence-based practice: panacea or over promise? Research Papers in Education, 18(4), 303-311. http://dx.doi.org/10.1080/02671520320 00176828

Slade, S., \& Prinsloo, P. 2013. Learning analytics ethical issues and dilemmas. American Behavioral Scientist, 57(10), 1510-1529. http://dx.doi. org/10.1177/0002764213479366

Steele, CK. 2014. Digital barbershops: The politics of African American oral culture in online blogs. Submitted as a partial fulfilment of the requirements for the degree of Doctor of Philosophy in Communication in the Graduate College of the University of Illinois at Chicago, Illinois. Retrieved from http://indigo.uic. edu/bitstream/handle/10027/19002/ Steele_Catherine.pdf?sequence $=1$

Swain, H. 2013, August 5. Are universities collecting too much information on staff and students? The Guardian. Retrieved from http://www.theguardian.com/ education/2013/aug/05/electronicdata-trail-huddersfield-loughboroughuniversity

Sweeney, ME., \& Brock, A. 2014. Critical informatics: New methods and practices. Proceedings of the American Society for Information Science and Technology, 51(1), 1-8. http://dx.doi.org/10.1002/ meet.2014.14505101032

Teichler, U. 2000. Higher education research and its institutional basis. In S. Schwarz \& U. Teichler (Eds.), The institutional basis of higher education research. Experiences and perspectives (pp. 13-24). London, UK: Kluwer Academic Publishers.

Teichler, U. 2003. The future of higher education and the future of higher education research. Tertiary Education \& Management, 9(3), 171-185. http:// dx.doi.org/10.1080/13583883.2003.99 67102

Tene, O., \& Polonetsky, J. 2012. Privacy in the age of big data: a time for big decisions. Stanford Law Review Online, 64, 63.

Terenzini, P. T. 1993. On the nature of institutional research and the knowledge and skills it requires. Research in Higher Education, 34(1), 1-10. http://dx.doi. org/10.1007/BF00991859 
Thrift, N. 2005. Knowing capitalism. London: Sage.

Totaro, P., \& Ninno, D. 2014. The concept of algorithm as an interpretive key of modern rationality. Theory Culture Society 31, 29-49. http://dx.doi. org/10.1177/0263276413510051

van Barneveld, A., Arnold, KE., \& Campbell, JP. 2012. Analytics in higher education: Establishing a common language. EDUCAUSE learning initiative, 1, 1-11.

van der Aalst, WM. 2014. Data scientist: The engineer of the future. In Enterprise Interoperability VI (pp. 13-26). Springer International Publishing. Retrieved from http://bpmcenter.org/wp-content/uploads/ reports/2013/BPM-13-30.pdf

Walker, MA. 2015. The professionalisation of data science. International Journal of Data Science, 1(1), 7-16. http://dx.doi. org/10.1504/JJDS.2015.069048

Watters, A. 2013, October 13. Student data is the new oil: MOOCs, metaphor, and money. [Web log post]. Retrieved from http://www.hackeducation. com/2013/10/17/student-data-is-thenew-oil/

Whitchurch, C. 2008. Shifting identities and blurring boundaries: The emergence of third space professionals in UK higher education. Higher Education Quarterly, 62(4), 377-396. http://dx.doi. org/10.1111/j.1468-2273.2008.00387.x

Whittemore, R., Chao, A., Jang, M., Minges, KE., \& Park, C. 2014. Methods for knowledge synthesis: an overview. Heart \& Lung: The Journal of Acute and Critical Care, 43(5), 453-461. http://dx.doi. org/10.1016/j.hrtlng.2014.05.014

Wishon, GD., \& Rome, J. 2012, August 13. Enabling a data-driven university. EDUCAUSEreview, [online]. Retrieved from http://www.educause.edu/ero/ article/enabling-data-driven-university

Zins, C. 2007. Conceptual approaches for defining data, information, and knowledge. Journal of the American society for information science and technology, 58(4), 479-493. http://dx.doi. org/10.1002/asi.20508 